\title{
BREXIT: CAUSES AND EXPECTED EFFECTS
}

\author{
Filip Ž. Bugarčić* \\ Faculty of Economics in Kragujevac \\ University of Kragujevac, Republic of Serbia \\ Marijana Simić \\ Faculty of Economics in Kragujevac \\ University of Kragujevac, Republic of Serbia
}

\begin{abstract}
The integration of countries and the formation of the common market, represent a desirable form of trade development and improving the level of development of individual economies. An example of a common market on the territory of Europe is the European Union, which has a unique legal and economic system applied by all member countries, as well as a unique system of customs and non-tariff barriers to nonmember countries. After the referendum held in June 2016, when the UK began the exit from EU, it turned out that not all countries shared the same views on the benefits from economic integration. Approximately $52 \%$ of citizens voted for exiting the EU when the withdrawal of this island country from the economic and political community of the European countries began. The aim of this paper is to identify the potential reasons for and effects of abandoning economic integration, based on Brexit case, as well as an assessment of the economic trends and effects that will occur in this particular case. Based on the results of the analyses carried out and collected secondary data, we can conclude that the causes and positive impact of Brexit will be felt only if the UK finds the best way for exiting the EU, which will almost certainly require a high degree of liberalization and maintenance of economic relations with the EU. This will enable the reduction of adverse effects, provide chances for the emergence of positive effects and justify the purpose of disintegration.
\end{abstract}

Key words: Brexit, European Union, Great Britain, economic integration, economic disintegration, common market, effects, reasons

JEL classification: F150, F160, F170

\footnotetext{
*fbugarcic@gmail.com
} 


\section{BREGZIT: RAZLOZI I OČEKIVANI EFEKTI}

Sažetak: Integracija zemalja i formiranje zajedničkog tržišta predstavlja poželjan oblik razvoja trgovine $i$ podizanja nivoa razvijenosti pojedinačnih privreda. Primer zajedničkog tržišta na teritoriji Evrope predstavlja Evropska unija, koja poseduje jedinstven pravni i ekonomski sistem primenjen od strane svih članica, kao i jedinstven sistem carina i necarinskih barijera prema zemljama nečlanicama. Nakon referenduma održanog u junu 2016. godine, čime je počelo istupanje Velike Britanije iz EU, pokazalo se da ne dele sve zemlje isto mišljenje kada su u pitanju koristi koje proizilaze iz ove ekonomske integracije. Približno 52\% glasača se izjasnilo za istupanje Velike Britanije iz EU čime je zvanično otpočeo proces istupanja ove ostrvske zemlje iz ekonomske i političke zajednice evropskih zemalja. Cilj ovog rada je identifikovanje potencijalnih razloga za napuštanje jedne ekonomske integracije, konkretno na primeru Bregzita, kao i ocena ekonomskih kretanja i efekata koji će nastupiti u ovom konkretnom slučaju. $\mathrm{Na}$ osnovu rezultata sprovedenih analiza i prikupljenih sekundarnih podataka izvodi se zaključak da će se razlozi i pozitivni efekti Bregzita ispoljiti tek u slučaju pronalaženja najboljeg načina za istupanje Velike Britanije iz EU, koji će gotovo sigurno zahtevati visok stepen liberalizacije i održavanja ekonomskih odnosa sa EU. Na ovaj način bi se omogućilo smanjenje negativnih posledica, obezbedile šanse za nastupanje pozitivnih efekata i opravdala svrha sprovođenja ove dezintegracije.

Ključne reči: Bregzit, Evropska unija, Velika Britanija, ekonomske integracije, ekonomska dezintegracija, zajedničko tržište, efekti, razlozi

\section{INTRODUCTION}

The Integration of countries in the form of economic and trade communities, as well as the formation of mutual market can be considered a desirable form for trade development and raising the level of single economies' development (Balassa, 2013). By creating economic integration, trade barriers are often reduced or even completely abolished which enables undisturbed trading and better economic interaction among member states that leads to better connections and convergence of economy segments. An example of a common market in Europe is the European Union (the EU further on in this text) which has a unique law and economic system applied by each member of the Union, as well as a unique system of customs and non-tariff barriers towards countries that are not members, that every Union member must comply with when it comes to international trade.This system proved to be convenient economic environment for efficent functioning of economies, which is also seen in desires 
and efforts of European countries in development to join the Union and encourage their own growth and development.

After the referendum in June 2016 and with the start of Great Britain's withdrawal from the EU, it turned out that not all countries share the same opinion when it comes to benefits from economic integration. Approximately $52 \%$ of voters were in favour of leaving the EU (Alagoa, 2017) which officially started the process of this country's withdrawal from economic and political community of European countries. This move shows the existence of certain deficiencies in the process of European integrations and reflects the desire of Great Britain's majority to continue further economic growth independently.

This raised numerous questions concerning further development of the situation and the way of dealing with numerous problems related to breaking up complicated connections between the EU and Great Britain. The process is definitely going to take a certain period of time, and require careful assessment of cost and benefits of such a decision. The withdrawal deadline is 31 October 2019, by which time crucial decisions must be reached. These decisions entail future relations between the Union and Great Britain, the ways of dealing with and solving certain questions, the status between Great Britain and other Union states, as well as the relationship between this "former member" and the rest of the world.

Considering the necessity to provide answers to the set of complicated questions that arose as a consequence of disintegration, the aim of this research is to identify and explain the reasons for the UK citizens' decision to exit the EU as well as to determine expected effects in short and long period of time. Over the a short period of time, it is possible to notice certain short-term effects of this process while long-term effects can be anticipated based on the motives for exiting and the way of forming and functioning of further economic movements and the relationship with foreign countries. The estimation of benefits and costs of exiting the EU takes some time. In the short run we can assume negative effects that Great Britain suffers after the decision. However, positive expectations from leaving EU are evident in the long run regarding the possibilities of independent operations and creation of economic policy, especially its foreign trade.

The basic aim of this paper is the identification of potential reasons that led Great Britain to exit EU, as well as the estimation of economic moves and effects that will follow in this case, on the basis of which the most acceptable scenario for both sides can be chosen. That is why analytical scientific method is used in this paper that enables to break down numerous factors, elements and information into simpler elements and thus identifying their relations. Besides, 
by using the methods of synthesis, that is the generalization of obtained data into more abstract, simpler judgements are connected into more complex ones.

The paper consists of several sections. After the introduction, a list of possible reasons why the majority of Great Britain's citizens voted for disintegration and leaving the EU is given. This process is called Brexit by scientific and professional public. The next part analyses economic effects of Brexit, and total benefits and costs of disintegration in this case, with special attention to expected long terms effects. In the end concluding considerations are given.

\section{THE REASONS FOR DISINTEGRATION AND THE EXIT OF GREAT BRITAIN FROM EUROPEAN UNION}

Somewhat unexpected referendum outcome regarding the exit of Great Britain from the EU (Ando, 2017) or popularly called Brexit, led to changes on the political scene of this island country as well as to general interest for reasons which led to this outcome. This decision is particularly surprising having in mind high level of integration among the EU countries and rare examples of leaving the $\mathrm{EU}^{1}$ especially by one of the leading European and World economies.

By analysing the evolution of UK's membership in the EU, it can be assumed that the outcome of this referendum was primarily the consequence of twenty year long campaign against the membership in the EU which started after Mastricht Treaty in 1992 and the formation of a single market in 1993. Besides, certain political parties claimed that sharing political power with the EU was undesirable restriction on British sovereignty. There was also a disagreement regarding free movement of workers on the territory of the entire Union and the UK wasn't willing to open its borders completely. Another disagreement concerned the jurisdiction of the Court of Justice of the European Union, which implied the waiving of national judiciary sovereignty (Sampson, 2017). Reasons mentioned imply that there was a solid base for the rise of dissatisfaction and desire to achieve a complete sovereignty and independence from the conditions that a union with other European countries required.

Possible reasons for the referendum outcome can also be found in the voting structure. Above all, education degree and voters' age can be idenfitied as the strongest demographic indicators of the achieved voting result. It is noticeable that with the increase of the voters' age, there is greater support for exiting the EU, whereby $60 \%$ of the population over 65 years of age were in favour of disintegration. According to the voters' education level structure, greater support for exiting the EU was given by voters without a University degree with

\footnotetext{
${ }^{1}$ Countries to leave EU were Algiers in 1962, Greenland in 1985 and St. Barthelemy in 2012.
} 
a support of $61 \%$ for exiting, while only $41 \%$ of voters with a University degree voted for Brexit (Becker, Fetzer and Novy, 2017). This attitude of voters points to low-skilled workers' concern for their jobs, because of the labour mobility concept entailed by the European Union integration, exposing them directly to competition of cheaper labour from less developed Union states. In addition, greater support for Brexit is present among households with lower income, below 20,000 pounds, which implies there is dissatisfaction with the current standard of living, while the support for Brexit was 10\% lower in households that have the income of more than 60,000 pounds per year (Goodwin and Oliver, 2016b).

Re-examining the validity of the disintegration in certain circumstances and the reasons for this aspiration, we can accept the views taken by Hobolt and De Vries (2016) by looking at three factors that evaluate the acceptance of economic integration: economic analysis of benefits and costs, evaluating the integration's usefulness itself and its identity as well as the information available to voters. The reason for the Brexit outcome cannot be precisely established, but keeping in mind the fact that the number of immigrants in Great Britain hugely increased in the period from 1995 to 2015, from $1,5 \%$ to 5,3\% of participation of other EU countries population (Wadsworth, Dhingra, Ottaviano and Van Reenen, 2016), it can be assumed that the fear of losing a job was one of decisive factors for this outcome.

One of the significant factors in favour of disintegration is the possibilty to pursue foreign trade policies and implement protectionist measures as well as independent forming of anti-dumping measures and measures on limiting the import of agricultural products (Hainmueller and Hopkins, 2014). On the one hand, the independent implementation of these measures protects domestic economy and gives a better chance to domestic manufacturers who support the implementation of national regulations advocating disintegration. On the other hand, integration demads that a country meets general standards in these areas which are often opposed to local population' needs and could cause a decline in their standard of living and general economic prosperity.

Great Britain decided to leave the EU Customs Union primarily for reasons of having the freedom to independently make free trade deals with other countries and create own foreign trade restrictions (Goodwin, 2017). This was impossible for the UK as a member of the EU since within the integration Great Britain was expected to apply common external tariffs to imports from other countries and was thus unable to impose independent customs rates, quotas and other non-tariff trade barriers. Besides, by independent control of the border the state secures that imported goods satisfy the prescribed internal regulations, ecological and other standards, provides confirmation about the goods' origin to 
show the share of goods produced in the country of export and keeps the possibility of prescribing and collecting appropriate amount of different kinds of import taxes.

Another reason in favour of Brexit is the possibility of introducing free and independent regulations and making laws that will affect business environment in the best manner. One of the important debates is about the law on the prevention of money laundering thanks to which the UK, after exiting, will be able to implement certain directives independently from the EU rule book and its supranational institutions (Mugarura, 2018). Besides legal and economic issues, there are cultural and sociological differences and other issues that are related to a specific way of life, British expectations and habits, as well as the belief that Great Britain as second European economy will function more efficiently after Brexit.

One of the arguments for exiting EU is that the UK will cease to contribute huge net amounts into the EU budget (Kotlinski, 2018). The UK is one of the countries that allocates the largest amunt of money to the EU budget, compared to expenses and benefits it receives from the EU's common resources (Matthews, 2016). The funds that the UK received from the EU budget in 2016 amunted to 7 billion euros, while the UK's contribution was 13,46 billion euros in the same year (European Commission, 2018). This data supports opposition to integration, pointing out negative aspects of Great Britain's membership in the Union giving quantitative data to support the restoring of the UK's complete sovereignt, impossible through membership in the EU.

Great Britain will continue to contribute funds and to fulfil its obligations according to established rules until it formally withdraws from the EU. As regards the reasons for the UK leaving the EU and the potential benefits to be gained from it, we have to emphasize the significance of the UK for the Union. It represents one of the most developed and richest members of the EU so the exit will affect the EU as well. The UK's contribution and its significance for the EU is seen in the fact that Union's budget has to be always balanced and that UK's share in the entire budget is 7\%. After the exit, other EU members are going to suffer because they will have to fill this gap in the budget by increasing their contribution from 7\% to 8,5\% (Aichele and Felbermayr, 2015). Brexit will especially affect less developed EU countries since they will have to increase their contribution while the EU will have to find the most harmless solution while constituting the model of future integration functioning. However, the question is whether Great Britain is going to completely stop all playments to the Union, keeping in mind that Norway and Switzerland are paying certain amount to the EU in return for access to common market and other benefits that come from different agreements with the EU. This question will depend on final 
agreement and whether Great Britain would want to stay within that common market, but what's certain is that it will surely have expenses related to previously arranged common programmes (Keep, 2018). We can notice concrete effects of future disintegration by looking at key macroeconomic indicators after the Brexit decision and possible trends in foreign trade policy of Great Britain and other EU state countries.

\section{ECONOMIC EFFECTS OF BREXIT - THE ANALYSIS OF BENEFITS AND COSTS OF DISINTEGRATION}

Brexit represents one of the most important events in recent economic and political history and its implications will affect both European and British economy. Referendum's result led to the wave of uncertainty regarding economy and financies, which could first be seen in the biggest depreciation of pound in the last 30 years (Nasir and Simpson, 2018). Sharp, short-term depreciation of domestic currency is a result of uncertainty regarding the future state and developments in financial and real sector.

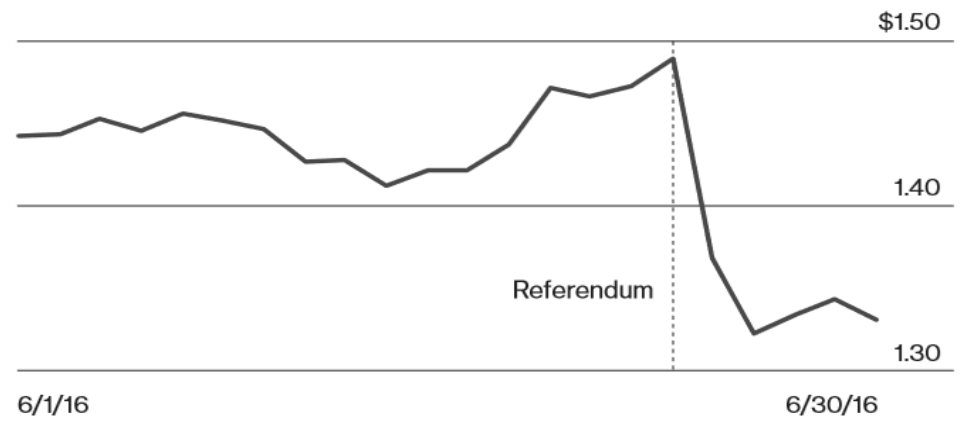

Figure 1. Movement of the Pound value in American Dollars after Brexit.

Note. Taken from The Brexit Short, Special Report Bloomberg Business week, $2^{\text {nd }}$ July, 2018.

By observing the British Pound exchange rate against the US Dollar we can see that its value has declined abruptly after the decision to leave the Union was taken. Until then $1 £$ was worth almost $1.50 \$$ but only several days after the referendum it drastically dropped to the value of something slightly above $1.30 \$$ for $1 £$. News about the referendum outcome reduced the value of the pound shortly after and its decline was one of the most drastic in the history of the modern financial system. This phenomenon showed the investors' current fear and the desire to abandon the British market because of the growing uncertainty which additionally discouraged and speeded up the domestic currency decline. Similar scenario, but to a lesser extent, also happened after Scotland's Independence Referendum when a certain number of investors, also because of 
disability to have clear insight into future developments, began to abandon Britain's territory which caused fluctuation of the pound's value and fluctuation of other macroeconomic indicators (Simpson, Finch and Chellel, 2018).

According to the Marshall-Lerner attitude, depreciation of the exchange rate can have a positive influence on the economy (Bahmani, Harvey and Hegerty, 2013). Depreciation can lead to the improvement of trade balance due to export increase or import decrease which will have positive effect on the balance of payments, but this doesn't accompany depreciation itself. Improving the exchange ratio would surely lead to positive effects, especially when it comes to an open economy such as Great Britain, where trade accounts for $62 \%$ of GDP. Thereof, export and import of goods account for $30 \%$ and services for the remaining 32\% (Office for National Statistics, 2016).

Ali Nasir and Simpson (Ali Nasir and Simpson, 2016), based on the empirical research conducted shortly after Brexit, concluded that the domestic currency value, that is its exchange rate, had significant implications for external balance and price stability in Great Britain. Depreciation of the pound, according to this research, led to international competitiveness increase and to a certain extent to rebalance of trade deficit, but the real effect will be felt only after making trade arrangements with other countries, especially with EU. Positive effect of depreciation will be manifested to a greater extent if, after leaving the Union, Britain keeps the existing trade arrangements, similar to those while being the EU member. In this case, this drastic drop in the pound would have better effect on Britain's international trade improvement.

The importance of trade agreements'extension with the EU so far is supported by the fact that the EU took $44 \%$ of Britain's total export, while $53 \%$ of the whole Britain's import was from countries of the Union. For comparison, we can state that entire trade of Great Britain with the EU was $320 \%$ bigger than the one with the USA, the second biggest trade partner. The importance of the EU for Great Britain can be best illustrated by Britain's exports to the EU which accounts for $12 \%$ of Britain's GDP, while on the other hand the imports from the EU accounts for only $3 \%$ of the EU GDP (World Bank, 2017).

Taking into consideration Britain's export to markets of individual countries (Figure 2), a great dependence on the EU countries becomes obvious. For that reason, a rational move would be to maintain the existing foreign trade relations after Brexit. After the USA, Britain's biggest individual foreign trade partners are developed members of the EU, so breaking the existing arrangements and abandoning common market would affect Britain's economy. Union members would also feel the consequences based on the level of international cooperation with Britain, and with some of them in some cases there is a double-digit percentage of the entire export directed towards Great Britain. 
Brexit effects can be evaluated by observing the industries that are most exposed by this decision. As Britain's biggest export sector, service sectors are singled out especially the segment of the financial and other business services.

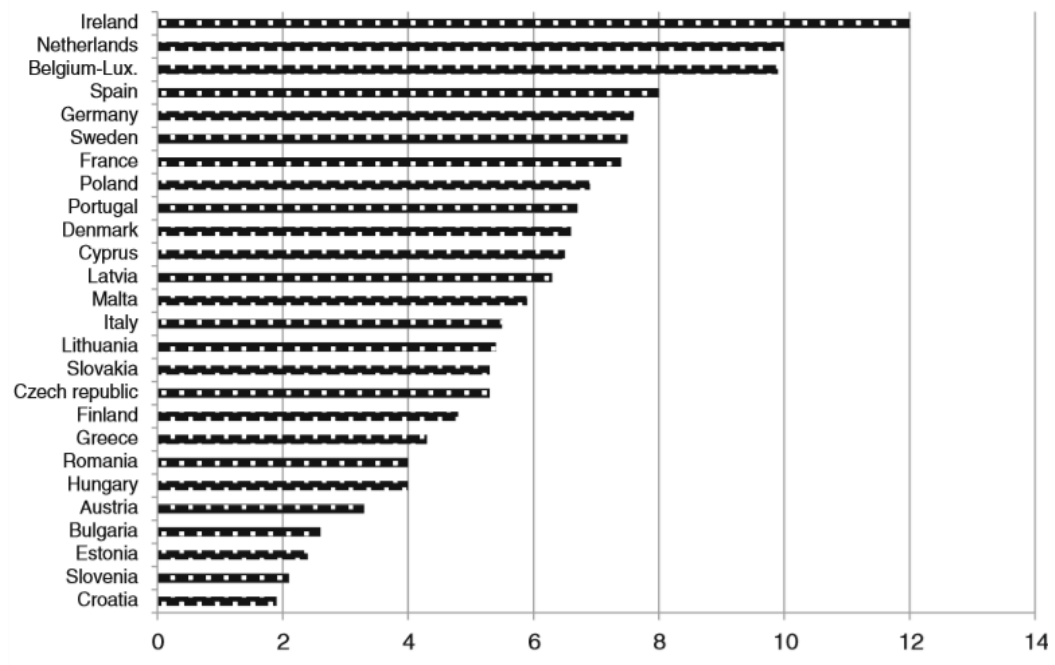

Figure 2. The percentage of participation of the total export of the EU countries towards Great Britain

Note. Taken from Observatory of Economic Complexity, 2017

This industrial segment is not subject to customs or any other quantitative restrictions, but attention should be paid to content and scope of future agreements that deal with financial and other services with the EU, mostly because of these sectors' domination, international service flow specifics and its high participation in Britain's export. When it comes to export of goods, the most dominant and most prone to Brexit influence are sectors of the car industry, chemical products, followed by mining, electronic and pharmaceutical industries, etc. These products will directly depend on future arrangement between Britain and the EU, in terms of the amount of customs duties and other non-tariff barriers that can drastically limit these products' export, and therefore the exported products' prices.

In Great Britain's economy private services are becoming more dominant, including the export combination (Begg, 2017). Regarding detailed manufacturing specialization, it is hard to determine decentralization's effects on the entire chain of production in certain industry and on the level of the given industrial sector. Complicated process of production and the necessity of integration of different manufacturing process phases will contribute to additional international obstacles, which, taking Great Britain as an example, could have negative effect on competitiveness. Every new trade restriction, like SCHOOL OF BUSINESS, 1/2019, 145-161 
imposing customs, could lead to fragmentation of the supply chain all around the EU in various industries (Cecchini, 1988). In that way, to Brexit costs of trade restrictions, additional costs of market fragmentation would be added.

Another important segment in Brexit case, when we talk about disintegration's economic effects, is the issue of direct foreign investments (DFI). Taking everything into account, EU-27 invested 7033 billion euros through DFI, while the income of this kind of investment in EU-27 was 5692 billion euros. Great Britain had a total investment of 1386 billion euros in the rest of the world, while receiving similar amount of this kind of investment from abroad, with the value of 1314 billion euros (Eurostat, 2017). Britain's investments into EU-27 of 683 billion euros seem proportionately to total DFI income in EU-27 (5692 billion euros) and represents $12 \%$ of total DFI on Britain's territory (1314 billion euros). The main reason for this situation is a great investment of the Netherlands in Great Britain, whose DFI reaches the value of 454 billion euros (Emerson, Busse, Di Salvo, Gros and Pelkmans, 2017).

Statistical estimations about DFI amount and structure are not completely representative and include many inaccuracies and internal contradictions. The first restriction is DFI's bilateral and multilateral mismatch. As the amounts of these investments can significantly differ depending on whether the data about the receiving country or about the investor are used, the data about the real amount of investments of certain countries could be misleading (Belke and Gros, 2017). Another thing is that this kind of investment is certainly more intense among countries that are members of some economic integration, but in Brexit case FDI's flow can be continued through the continuation of bilateral and multilateral cooperation with previous investors.

When it comes to macroeconomic indicators, besides the exchange rate, which was relatively stable and without significant fluctuations before the referendum, the effect of the vote was reflected in inflation rates and earnings growth in Great Britain as well (Figure 3). After June, 2016, the inflation started to go up from $1.2 \%$ in June to almost $1.5 \%$ after less than a year. Besides, another significant effect of macroeconomic stability is the real earnings which started to drop shortly after the referendum. More significant decline of this value was seen at the end of 2016, so that at the beginning of 2017 real earnings growth started to record negative values of $-0.5 \%$. This change is not negligible having in mind that at the beginning of 2016, just before the referendum, an average earnings growth was from $1.5 \%$ to $2 \%$ (Office for National Statistics, 2016). In the middle of 2017, only a year after citizens' decision to leave the EU, all the observed parametres were in much worse position. This shows a negative shock which struck British economy shortly after the Brexit decision. However only after a certain period of time it would be possible to establish long-term 
consequences of this develpments and their effects both on British economy and macroeconomic environment in EU-27.

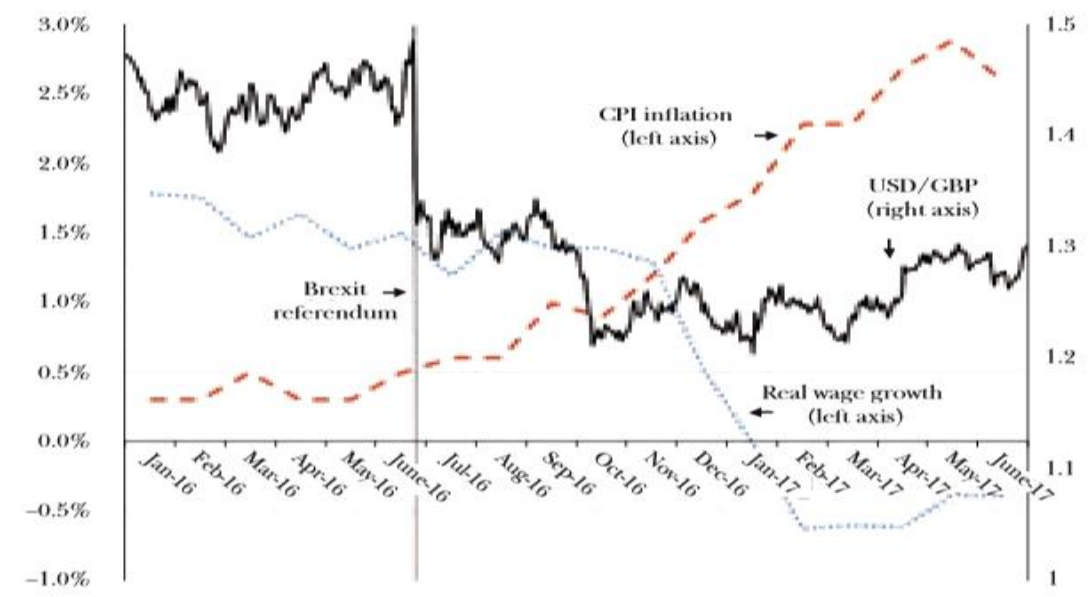

Figure 3. The exchange rate, inflation and the growth of real earnings before and after Brexit

Note. Taken from Office for National Statistics, Great Britain, 2017.

\section{EXPECTED LONG-TERM EFFECTS}

The assessment of Brexit long-term effects can be seen through careful specification and examination of certain conditions for leaving the EU based on identified different scenarios. For example, assessments made by HM Treasury (Treasury, 2016) provided the opportunity of considering several potential scenarios. One of them is leaving the EU but with different effects depending on whether they are going to have full access to common market, similar to Norwegian model, or make some trade arrangement with the EU like Canada did. In addition, a possible scenario implies leaving the common market, and in spite of bilateral arrangements, strict adherence to standard rules given by World Trade Organization (WTO). By analysing these scenarios it is clear that the best (least harmful) outcome of the future situation, for GDP and work places, would be to use the Norwegian model to access the common market with the EU, which would make the position of Britain's international trade with the EU the most similar to the previous one. The worst case scenario would be to leave the common market without any other agreements and accepting WTO's strict rules (Begg, 2017).

There is a big difference in results of the different analyses. Estimates go from pessimistic drops of Britain's GDP of almost 10\% (Ebell and Warren, 2016) to optimistic scenarios with GDP growth of 4\% (Minford and Gupta, 2016). SCHOOL OF BUSINESS, 1/2019, 145-161 
Generally speaking, based on all previous research, the least harmful scenario for Great Britain's interest is the one that includes the lowest restriction degree on Britain's future access to the EU market, while those that result in new trade and investment barriers would cause most harm to future development.

Except for Great Britain, European and other world economies will also feel the consequences of Brexit, but to a lesser degree than the British economy. Brexit is equivalent to consumption decline per capita in the EU from optimistic $0,14 \%$ to pessimistic $0,35 \%$. Countries that are not members of the EU could benefit from Brexit due to trade diversion, but positive effects are quantitatively negligible compared to losses that Britain and the EU are dealing with (Sampson, 2017). Figure 4 shows estimated Brexit effects, according to optimistic and pessimistic scenarios, for various world economies, where optimistic scenario implies the common market of Britain and the EU, while the pessimistic one implies establishing trade and foreign trade relations according to the WTO principles. It is noticeable that among observed countries negative effects would affect all European economies, while other non-European economies could have a minimal profit from this, but disproportionately to potential losses of European countries.

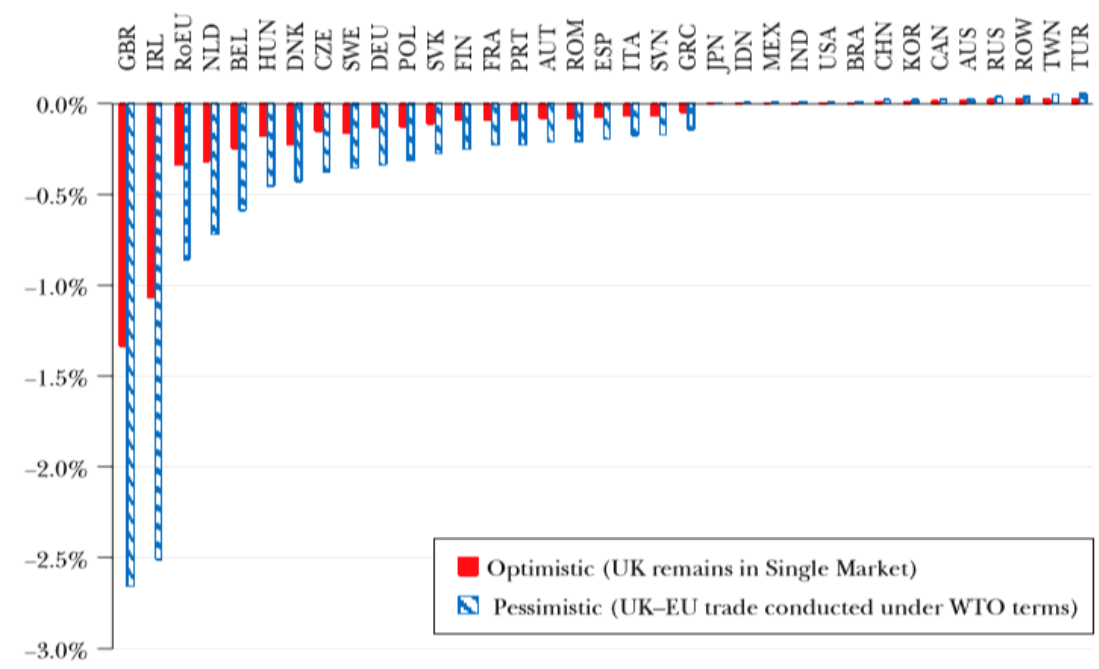

Figure 4. Estimated Brexit effects according to optimistic and pessimistic scenario (\% income change per capita).

Note. Dhingra, S., Huang, H., Ottaviano, G., Paulo Pessoa, J., Sampson, T., \& Van Reenen, J. (2017). The costs and benefits of leaving the EU: trade effects. Economic Policy, 32(92), 651-705.

A frequently asked question is how Europe will look like after Brexit and what kind of damage it will suffer. Based on some projections according to the 
International Monetary Fund's data, presented by the Financial Times, the world economy would look different. According to this estimation, the exit of Britain means that the EU economy would become smaller than the one of the USA, unlike in the present situation where EU-28 has an advantage in GDP growth of $1 \%$ over the GDP growth in the USA. The loss of such a great economy, second biggest in Europe after Germany, which makes $12 \%$ of the EU's GDP, will inevitably have significant influence on the world economy and future deployment of forces. However, even if Great Britain was the trigger of EU's growth in the previous period, its contribution decreased during past few years and the growth of GDP came close to the EU's average. The key question as to how Britain is going to withdraw from the EU, concerns the appearance and content of future trade agreements with EU members. What the effects of this disintegration would be on GDP's growth can be seen from another Brexit outcome analysis, carried out by Goodwin (Goodwin, 2017). According to this research, looking at wider economy influence, one option is for Great Britain to negotiate an agreement about free trade with the EU but with a total customs control, which would result in the GDP level between $0.7 \%$ and $1.3 \%$ lower in 2030 than if Britain stayed in the EU customs Union (Figure 5). This difference in GDP decrease would be the result of Government's measures in the coming period, and whether liberal or populist politics would prevail.

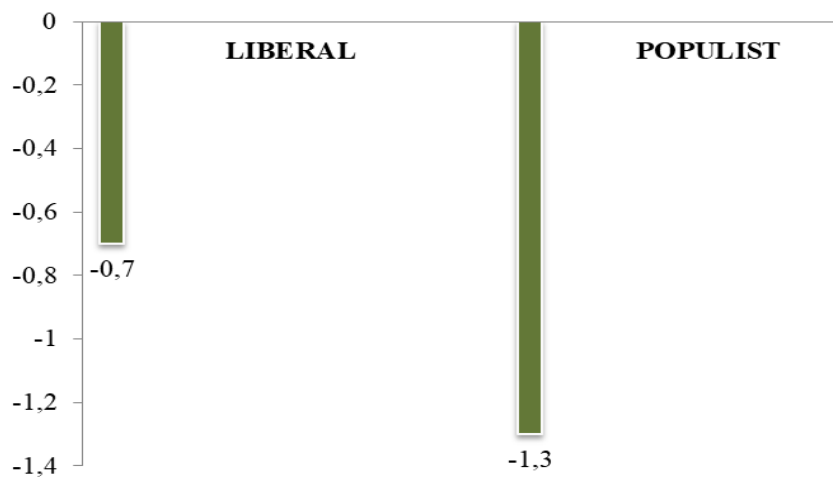

Figure 5. The effect of Britain exiting customs Union of EU to GDP growth Note. Goodwin, A. (2017). Brexit - Customs borders will impose costs and delays. Oxford Economics.

This negative effect could be reduced by the continuation of Britain's and EU's cooperation in the common market and through agreements about the free trade with other leading world economies. Independence in defining foreign trade barriers represents the main motive for disintegration. However, considering the complexity of international trade negotiations and probability that Great Britain would more likely make an agreement about free trade with the EU, which is its 
biggest market at the same time, it can be expected that benefits from new agreement about free trade would come only much later.

\section{CONCLUSION}

Aspiration of the majority of British citizans to leave the EU is the consequence of their wish for independence in designing economic policy and making decisions and their wish to regain the full national sovereignty that was partially limited within the EU. Besides, the concern about jobs and the future of migration within the EU led to such a referendum outcome. It was evident that citizens of Britain wanted to protect themselves from potential loss of jobs and wages cuts due to increase of migrants arriving to the European continent in the past few years. The important prerequisite of the independence is the adequate and timely effect of the macroeconomic policy, which would allow the British after Brexit to make decisions independently and to establish their own rules for the welfare of its citizens and to increase the level of prosperity of the domestic economy. Another reason is the large net sum of money that Britain allocates to the EU budget, but according to its citizens, adequate benefits are not gained from the alliance in return.

By observing short term effects of the Brexit through the course of exchange rate, inflation and the growth of real earnings immediately after the referendum, a conclusion can be made that the decision of British citizens to leave the EU looks impromptu or at least that it cannot bring any direct benefits in short term. With the improvement of British international position, the negative trend of macroeconomic indicators could lead to positive effects. Whether this would happen, depends on future international foreign trade agreements with other countries and relations with the $\mathrm{EU}$ as its most important foreign trade partner.

Staying inside EU's common market and Customs Union seems like the most favourable Brexit scenario, having in mind that the British economy has a high level of dependency and cooperation with members of the Union, both regarding import and export and investments, most of which come from the EU countries. Special attention must be given to leading British industry sectors and finding most favourable bilateral and multilateral arrangements for the most efficient solution of the newly created situation, which will also have the least negative effects on domestic industry and the position of Britain in international economic relations. All predictions regarding Brexit's efficiency in terms of its impact on future economic trends in Britain, point to the closest possible relation with the EU, but also to necessity of finding new markets that would compensate for the loss made by leaving the Union.

Disintegration effects will be felt by the EU countries as well, but to a lesser extent. As a whole, EU-27 will be weakened by the withdrawal of the second 
largest economy and will also be forced to compensate for the loss. Other World countries will be able to make a certain profit, primarily due to changes in trading directions that will follow after Brexit, but to smaller extent than the level of threat disintegration will impose on the EU countries and Britain itself. The overall conclusion is then that the positive effects of Brexit will only be manifested in case of finding the most favourable solution for Britain to leave the EU, where it is desirable to establish a high level of liberalization. It is important to maintain economic relations with the EU, most similar to present ones, which implies staying within the common market and preserving existing trading and other development arrangements. This would reduce negative consequences and induce positive effects that could justify the initial causes and purpose of disintegration.

\section{REFERENCES}

Aichele, R., \& Felbermayr, G. (2015). Cost and benefits of a United Kingdom exit from the European Union.

Alagoa, H. (2017). Brexit, Trade, and the Wealth of Nations. Available at SSRN 2985022.

Ando, K. (2017). Brexit: A new institutional economics perspective. European Association for Evolutionary Political Economy

Bahmani, M., Harvey, H., \& Hegerty, S. W. (2013). Empirical tests of the Marshall-Lerner condition: a literature review. Journal of Economic Studies, 40(3), 411-443.

Balassa, B. (2013). The theory of economic integration (routledge revivals). Routledge.

Becker, S. O., Fetzer, T., \& Novy, D. (2017). Who voted for Brexit? A comprehensive district-level analysis. Economic Policy, 32(92), 601-650.

Begg, I. (2017). Making sense of the costs and benefits of Brexit: challenges for economists. Atlantic Economic Journal, 45(3), 299-315.

Belke, A., \& Gros, D. (2017). The economic impact of Brexit: Evidence from modelling free trade agreements. Atlantic Economic Journal, 45(3), 317331.

Campos, N. F. (2019). B for Brexit: A Survey of the Economics Academic Literature.

Cecchini, P. (1988). The European challenge, 1992: The benefits of a single market. Aldershot: Gower. 
Connolly, B. (2018). The Continued Case for Brexit. The International Economy, 32(4), 16-66.

Dhingra, S., Huang, H., Ottaviano, G., Paulo Pessoa, J., Sampson, T., \& Van Reenen, J. (2017). The costs and benefits of leaving the EU: trade effects. Economic Policy, $32(92), 651-705$.

Ebell, M., \& Warren, J. (2016). The long-term economic impact of leaving the EU. National Institute Economic Review, 236(1), 121-138.

Emerson, M., Busse, M., Di Salvo, M., Gros, D., \& Pelkmans, J. (2017). An assessment of the economic impact of Brexit on the EU27: Study. Policy department A: Economic and Scientific policy, European Parliament.

European Commission. (2018). Budgets and funding. How much does the UK contribute and receive? European Commission.

Eurostat. (2017). Your key to European statistics. Retrieved from http://ec.europa.eu/eurostat/data/database?p_p_id=NavTreeportletprod_ WAR_NavTreeportletprod_INSTANCE_nPqeVbPXRmWQ\&p_p_lifecy cle $=0 \&$ p_p_state $=$ normal $\&$ p_p_mode $=$ view $\&$ p_p_col_id $=$ column 2\&p_p_col_count=1.

Goodwin, A. (2017). Brexit - Customs borders will impose costs and delays. Oxford Economics.

Goodwin, M., \& Heath, O. (2016). Brexit vote explained: poverty, low skills and lack of opportunities. Joseph Rowntree Foundation, 31.

Hainmueller, J., \& Hopkins, D. J. (2014). Public attitudes toward immigration. Annual Review of Political Science, 17, 225-249.

Hobolt, S. B., \& de Vries, C. E. (2016). Public support for European integration. Annual Review of Political Science, 19, 413-432.

Keep, M. (2018). The UK's contribution to the EU budget. House of Commons Briefing Paper.

Kotliński, K. (2018). The economic consequences of leaving European Union by Great Britain. Economics and Law, 17(2), 157-167.

Matthews, A. (2016). The Potential Implications of a Brexit for Future EU Agri-food Policies. EuroChoices, 15(2), 17-23.

Minford, P., \& Gupta, S. (2016). Should Britain leave the EU? An economic analysis of a troubled relationship. London: Institute of Economic Affairs.

Minford, P., \& Xu, Y. (2018). Classical or Gravity? Which trade model best matches the UK facts? Open Economies Review, 29(3), 579-611. 
Mugarura, N. (2018). The implications of Brexit for UK anti-money laundering regulations: Will the fourth AML directive be implemented or be binned?. Journal of Money Laundering Control, 21(1), 5-21.

Nasir, M. A., \& Simpson, J. (2018). Brexit associated sharp depreciation and implications for UK's inflation and balance of payments. Journal of Economic Studies, 45(2), 231-246.

Niederjohn, S., Harrison, A., \& Clark, J. R. (2017). The Economics of Brexit. Social Education, 81(2), 84-87.

Office for National Statistics. (2016). Statistical Bulletins: UK Trade. Office for National Statistics.

Sampson, T. (2017). Brexit: the economics of international disintegration. Journal of Economic Perspectives, 31(4), 163-84.

Simpson, C., Finch, G., \& Chellel, K. (2018). The Brexit Short. Bloomberg Businessweek.

Treasury, H. M. (2016). HM Treasury analysis: the long-term economic impact of EU membership and the alternatives. Parliament by the Chancellor of the Exchequer by command of Her Majesty.

Wadsworth, J., Dhingra, S., Ottaviano, G., \& Van Reenen, J. (2016). Brexit and the Impact of Immigration on the UK. CEP Brexit Analysis, 5, 34-53.

World Bank. (2017). World Development Indicators. World Bank.

Delivered: 16.10.2018. Accepted: 29.11.2019. 